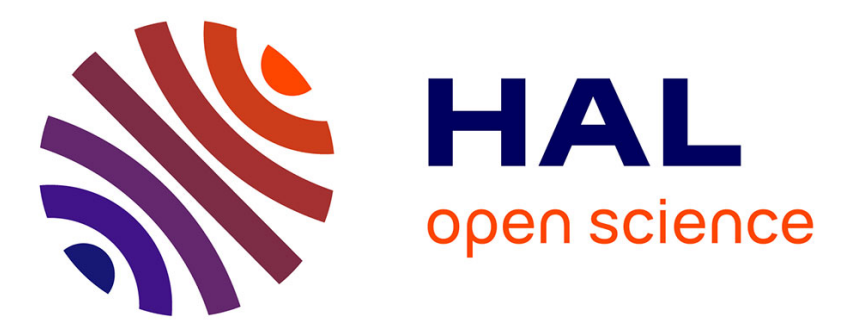

\title{
Phosphonated Podand Type Ligand for the Complexation of Lanthanide Cations
}

\author{
C. Charpentier, J. Salaam, A. Lecointre, O. Jeannin, A. Nonat, L.J.
} Charbonnière

\section{- To cite this version:}

C. Charpentier, J. Salaam, A. Lecointre, O. Jeannin, A. Nonat, et al.. Phosphonated Podand Type Ligand for the Complexation of Lanthanide Cations. European Journal of Inorganic Chemistry, 2019, 2019 (16), pp.2168-2174. 10.1002/ejic.201900069 . hal-02122174

\section{HAL Id: hal-02122174 \\ https://hal-univ-rennes1.archives-ouvertes.fr/hal-02122174}

Submitted on 18 Jul 2019

HAL is a multi-disciplinary open access archive for the deposit and dissemination of scientific research documents, whether they are published or not. The documents may come from teaching and research institutions in France or abroad, or from public or private research centers.
L'archive ouverte pluridisciplinaire HAL, est destinée au dépôt et à la diffusion de documents scientifiques de niveau recherche, publiés ou non, émanant des établissements d'enseignement et de recherche français ou étrangers, des laboratoires publics ou privés. 


\title{
Phosphonated podand type ligand for the complexation of lanthanide cations
}

Cyrille Charpentier, ${ }^{\mathrm{a}}$ Jérémy Salaam, ${ }^{\mathrm{a}}$ Alexandre Lecointre, ${ }^{\mathrm{a}}$ Olivier Jeannin, ${ }^{\mathrm{b}}$ Aline Nonat, ${ }^{\mathrm{a}}$ Loïc J. Charbonnière ${ }^{a *}$

${ }^{a}$ Mr C. Charpentier, Mr J. Salaam, Mr A. Lecointre, Dr A. Nonat, Dr L.J. Charbonnière Equipe de synthèse pour l'analyse (SynPA), Institut Pluridisciplinaire Hubert Curien (IPHC, UMR 7178), CNRS/Université de Strasbourg, ECPM, 25 rue Becquerel, 67087 Strasbourg Cedex, France. E-mail : 1.charbonn@unistra.fr

${ }^{\mathrm{b}}$ Dr O. Jeannin, Université de Rennes, CNRS, ISCR-UMR6226, F-35000 Rennes, France

\begin{abstract}
A new tripodal ligand, based on a central nitrogen atom tris-functionalized with 6methylene-2-pyridyl phosphonic acid was synthesized and characterized, in particular by its Xray crystal structure. The coordination behaviour of the tripod with lanthanide cations in aqueous solutions was studied by means of UV-Vis electronic absorption spectroscopy and steady-state and time-resolved luminescence spectroscopy, revealing the formation of a [LnL] complex followed by polynuclear species with 2:1 and 3:1 metal:ligand stoechiometries. The [LnL] complexes $(\mathrm{Ln}=\mathrm{Eu}, \mathrm{Tb}$ and $\mathrm{Yb})$ were isolated and characterized and the solid state structure of the Eu complex was determined by X-ray diffraction analysis on monocrystals, revealing the observation of dimeric species, in which the $\mathrm{Ln}^{3+}$ cations are firmly held in the cavity formed by the three pyridylphosphonate arms, the coordination of the cations being completed by a water molecule and a phosphonate function of the second complex, allowing for the formation of the dimers, which are further stabilized by $\pi$ - $\pi$ stacking interactions between one pyridyl unit of each adjacent monomer. The spectroscopic properties of the complexes in aqueous solutions were studied, showing an impressive $16 \mu$ s excited state
\end{abstract}


lifetime for the $\mathrm{Yb}$ complex in $\mathrm{D}_{2} \mathrm{O}$, despite the presence of a water molecule in the first coordination sphere.

\section{Introduction}

Lanthanide complexes are displaying exceptional magnetic and spectroscopic properties that make this family of complexes of particular interest in the design of probes for biomedical applications in the various fields of MRI imaging, ${ }^{1}$ luminescence microscopy ${ }^{2}$ or bio-analysis. ${ }^{3}$ However, despite the plethora of complexes that one can find in the literature, there is still room for the design of new ligands and structures displaying improved properties and phosphonated ligands, while still scarce in the literature, are among such. ${ }^{4}$

The coordination chemistry of phosphonate functions with Ln cations can be quite complicated by the various binding modes which can be adopted. ${ }^{5}$ It is not rare to see that the three oxygen atoms of the function can take part into coordination of numerous Ln cations in the solid state, such as the pentadentate coordination observed in some structures of aminophosphonate complexes of $\mathrm{Gd},{ }^{6}$ or the bridging mono- or bidentate modes of Ln helical structures. ${ }^{7}$ However, phosphonate functions are also bringing numerous advantages, replacing favourably their carboxylate counterparts on a thermodynamic point of view ${ }^{8}$ with a larger steric hindrance that may allow to exclude water molecules from the first coordination sphere such as in the DOTP complexes, ${ }^{9}$ having a double negative charge around neutral $\mathrm{pH}$, and bringing very important second sphere interactions, which can be advantageously used for MRI contrast agents for example. ${ }^{10}$ The second sphere interactions of phosphonated complexes of lanthanide cations are also at the origin of intriguing behaviours in solution. It was soon recognized by Horrocks and co-workers that $\mathrm{Eu}^{11}$ or $\mathrm{Ce}^{12}$ with polyaminophosphonated ligands like ethylenediaminetetrakis(methylphosphonic) acid or diethylenetriaminepentakis(methylphosphonic) acid formed M:L complexes of $1: 1$ and 2:1 stoechiometric coefficients, the composition of which was strongly dependent on the $\mathrm{pH}$ of the solutions. The presence of numerous phosphonate functions resulted in potentially large negative charges on the complexes, which may interact with additional $\mathrm{Ln}^{3+}$ cations in the solution to form polynuclear species. In view of recent results on polyphosphonated Ln complexes integrating other analyticals tools such as mass spectrometry, ${ }^{13,14}$ it appears that the composition of such adducts can be even larger with the potential formation of tri- to pentanuclear species, the composition of which can be adjusted to obtained pure 
heteropolynuclear species with exceptional spectroscopic properties such as molecular upconversion in heavy water ${ }^{15}$ and more recently in pure water. ${ }^{16}$

In an effort to understand the structure/activity relationship in these edifices, we anticipated that ligand $\mathbf{L H}_{6}$ (Scheme 1), with its $C_{3}$ symmetry, might be of particular interest to form polyphosphonated complexes with Ln cations and potentially more elaborated structures. In this contribution, the coordination behaviour of $\mathrm{LH}_{6}$ with different $\mathrm{Ln}^{3+}$ cations is questioned with different spectroscopic and analytical means, revealing once again a quite complex coordination ability.<smiles>O=P(O)(O)c1cccc(CN(Cc2cccc(P(=O)(O)O)n2)Cc2cccc(P(=O)(O)O)n2)n1</smiles>

Scheme 1

\section{Results and discussion}

Synthesis of the ligand. The tripodal ligand $\mathbf{L}$ can be readily obtained at the gram scale according to the synthetic procedure presented in Scheme 2.<smiles>ClCc1ccccn1</smiles>

1
1) $m$-CPBA

2) CICOOEt, $\mathrm{P}(\mathrm{OEt})_{3}$<smiles>COc1cccc(CCl)n1</smiles>

2
3) $\left(\mathrm{C}_{2} \mathrm{H}_{5} \mathrm{~N}\right)_{3}$,<smiles>CC(C)(C)c1cccc(PO[Na])n1</smiles><smiles>[X]C1CCCCC1=[X]</smiles>

Scheme 2. Synthetic procedure for the preparation of ligand $\mathbf{L}\left(\left(\mathrm{C}_{2} \mathrm{H}_{5} \mathrm{~N}\right)_{3}\right.$ is acetaldehyde ammonia trimer $)^{17}$

Starting from the commercially available 2-chloromethyl-pyridine 1, N-oxydation using $\mathrm{m}-\mathrm{CPBA}$ in chloroform afforded the corresponding pyridine-N-oxyde, which is functionalized 
into the $o$-phosphonic ethyl ester $\mathbf{2}$ by reaction with ethyl chloroformate and triethyl phosphite according to literature procedures. ${ }^{13}$ The formation of the tripod was achieved in $42 \%$ yield by adaptation of a procedure developed by Mikata and co-workers using acetaldehyde ammonia trimer. ${ }^{17}$ Interestingly, other attempts conducted with $\mathrm{NH}_{4} \mathrm{Cl}$ as amine source seemed to show that the alkylation steps are successively favoured, the third and second alkylations being more rapid than the first one, potentially as a result of an increase of the nucleophilicity of the formed amines upon introduction of the methyl-pyridyl substituents. Although there is a supplementary pyridyl unit in our case, this point may be related to the increase of the $p K a$ values of the amines observed in aminomethyl phosphonic acid upon introduction of the phosphonic acid moieties. ${ }^{8 a, 18}$ The ligand was finally obtained by acid hydrolysis of the ethyl phosphonic esters followed. Dissolution of the ligand in hot water followed by slow cooling of the solution afforded nice cubic crystals which could be used for the solid state structure determination by X-ray diffraction. Crystal data and structure refinement are summarized in Table S1 (Supp. Inf.).

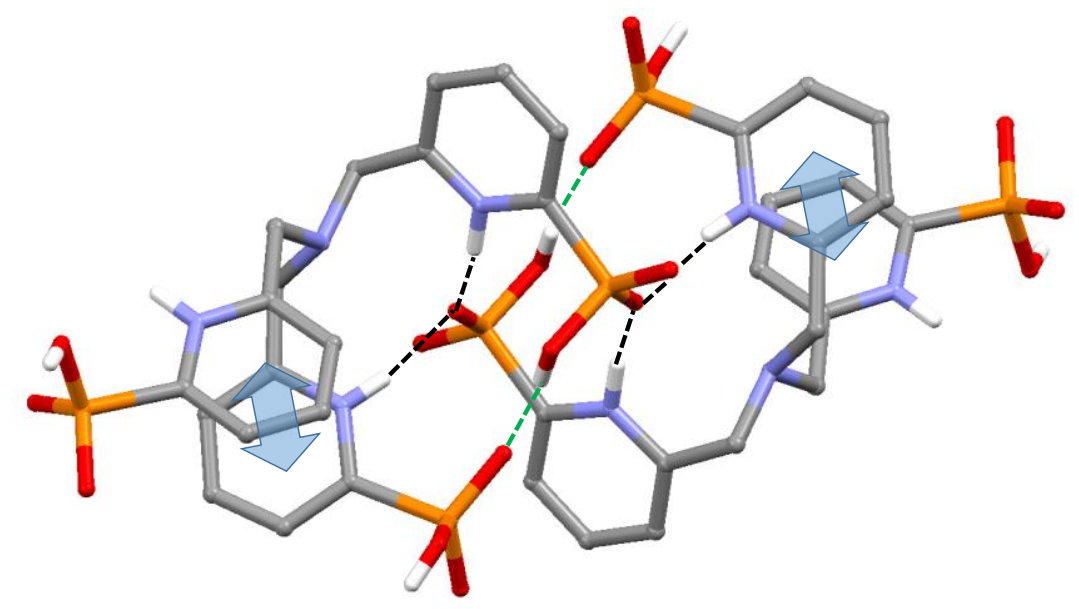

Figure 1. X-ray crystal structure of a dimer of the ligand $\mathbf{L H}_{6}$ in the solid state. $\mathrm{H}$ atoms have been omitted for the sake of clarity except for those of pyridinium and phosphonate functions. Blue double arrows represent intramolecular stacking interactions and black and green dotted lines represent intermolecular and intramolecular hydrogen bonds, respectively.

The structure is composed of a molecule of the ligand in its fully protonated state $\mathbf{L H}_{6}$ and two water molecules. A striking feature of the protonation is that the pyridyl phosphonic acid functions are found in a zwitterionic state, each pyridyl ring being protonated while the phosphonic acids are mono-deprotonated. The different labile proton atoms are implicated in an intricate network of $\mathrm{H}$ bonding interactions, also implying the two water molecules. Another 
striking feature of the ligand is the formation of an intramolecular $\pi-\pi$ stacking interaction between two pyridyl rings with their mean centroid distance at $3.608 \AA$ and an angle of $23.7^{\circ}$ between the average planes formed by the aromatic rings. Noteworthy, the orientation of the two rings are opposite, with the pyridinium bonds pointing in opposite direction, better than being aligned. This may result from a lower energy of the interaction between the dipoles, together with a lower steric interaction of the phosphonic acid functions which would have overlap otherwise. Also of interest, ligands are related by pairs in which, one of the phosphonate function is hydrogen bonded to two pyridinium $\mathrm{H}$ atoms of the second ligand. Finally, and intermolecular $\mathrm{H}$ bonding interactions is present in a ligand between the $\mathrm{H}$ and $\mathrm{O}$ atoms of two phosphonate functions (green dotted line in Figure 1).

\section{Spectroscopic titrations of $\mathrm{L} \mathrm{by} \mathrm{Ln}^{3+}$ cations.}

In order to get insights into the coordination behaviour of the ligand with lanthanide cations, we first performed a series of spectrophotometric titrations monitored by UV-Vis electronic absorption spectroscopy and luminescence spectroscopy. In a typical experiment, ${ }^{19}$ the spectra of the ligand solution were recorded after addition of increasing aliquots of the metal in a buffered aqueous solution (TRIS/HCl $0.01 \mathrm{M}, \mathrm{pH}=7.1$ ). Figure 2 represents a typical example for the UV-Vis absorption titration of $\mathbf{L}$ by $\mathrm{Eu}^{3+}$, while Figure 3 represents the evolution of the Eu centred emission upon excitation into the ligand bands. The same titration experiments with $\mathrm{Tb}^{3+}$ can be found in Figure S1 and S2 of the supplementary information.

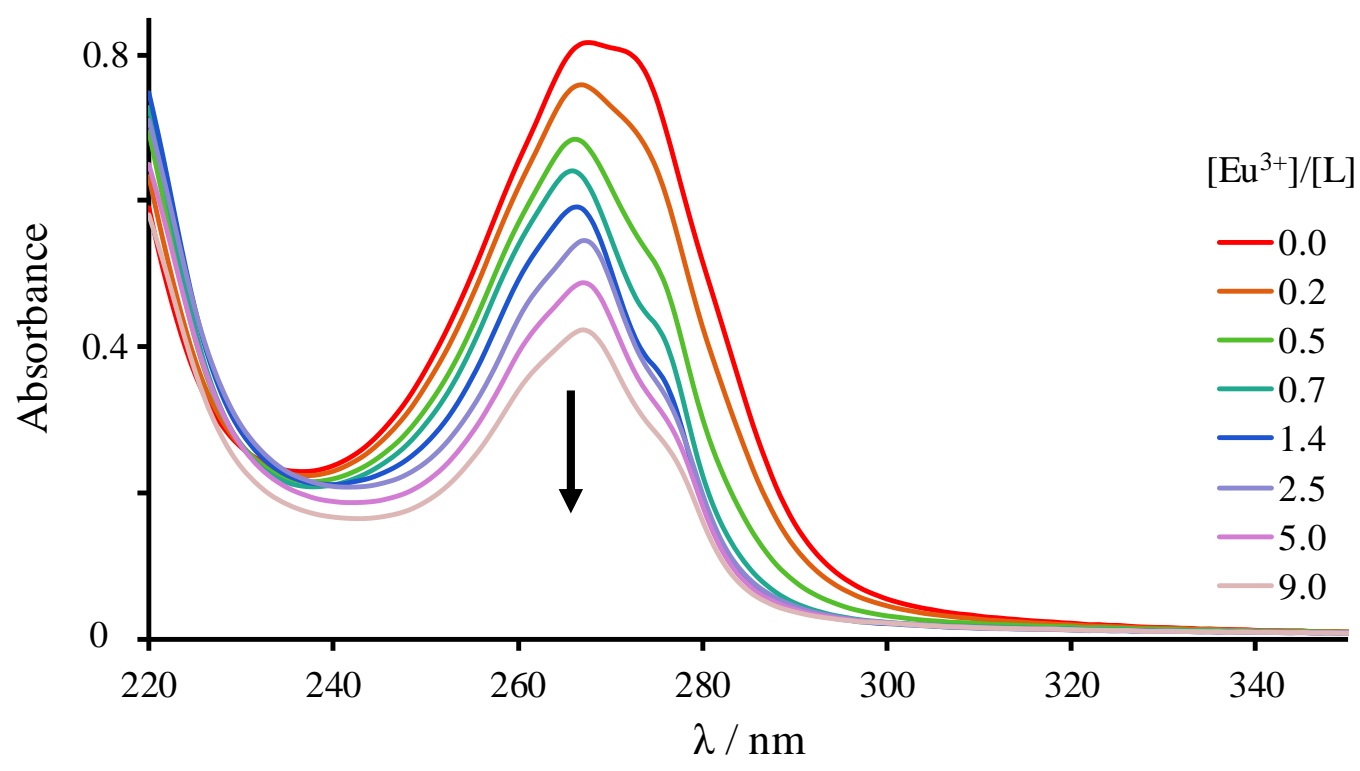


Figure 2. Evolution of the UV-Vis absorption spectra of a solution of $\mathbf{L}$ upon titration by $\mathrm{EuCl}_{3}$ (0.01 M TRIS/HCl, $\mathrm{pH}=7.1)$.

As can be seen in Figure 2, the UV-Vis absorption spectrum of the free ligand is dominated by the intense $\pi \rightarrow \pi^{*}$ transitions of the pyridine units at $267 \mathrm{~nm}\left(\varepsilon=14700 \mathrm{M}^{-1} . \mathrm{cm}^{-1}\right)$. During the different titration experiments, this maximum is almost not displaced and only the relative intensity of this transition and its shape, a shoulder appearing at $c a 275 \mathrm{~nm}$ upon Eu addition, could be used in the fitting of the data.

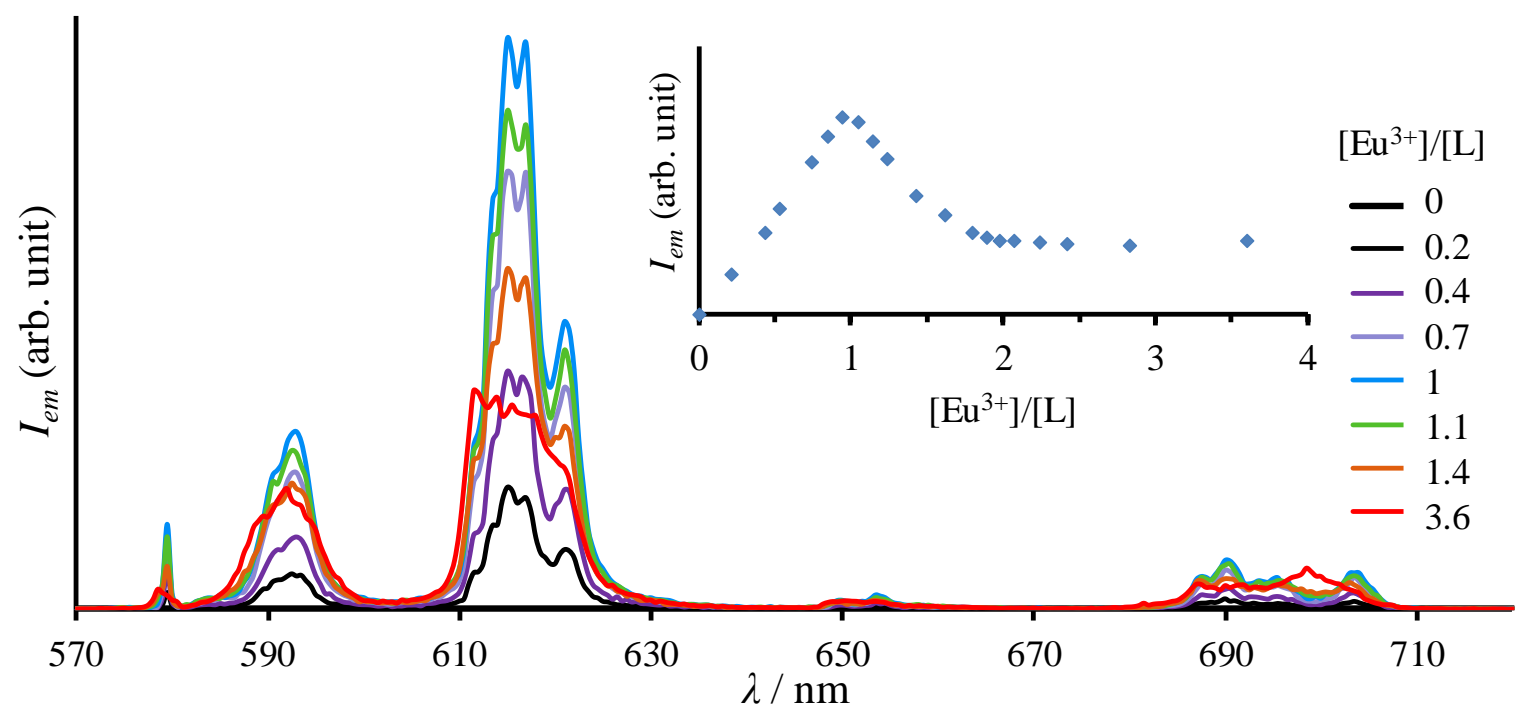

Figure 3. Evolution of the luminescence spectra of a solution of $\mathbf{L}$ upon titration by $\mathrm{EuCl}_{3}(0.01$ $\mathrm{M}$ TRIS/HCl, $\left.\mathrm{pH}=7.1, \lambda_{e x c}=267 \mathrm{~nm}\right)$. Inset: Evolution of the emission intensity at $616 \mathrm{~nm}$ as a function of the $\left[\mathrm{Eu}^{3+}\right] /[\mathrm{L}]$ ratio. $[\mathrm{L}]=5.0 \times 10^{-5} \mathrm{M}$.

In contrast the luminescence titrations were particularly informative. In the case of Eu, addition of the metal immediately led to the observation of the typical emission spectra of $\mathrm{Eu}$ complexes with the ${ }^{5} \mathrm{D}_{0} \rightarrow{ }^{7} \mathrm{~F}_{\mathrm{J}}(\mathrm{J}=0$ to 4$)$ transitions of $\mathrm{Eu}^{20}$ Further additions of $\mathrm{EuCl}_{3}$ in the solution gave rise to an increase of the emission intensity of all transitions (Figure 2). Above one equivalent of lanthanide salt, strong changes in the shape of the transitions were observed, indicating the formation of additional species in solution. The most significant changes were observed on the ${ }^{5} \mathrm{D}_{0} \rightarrow{ }^{7} \mathrm{~F}_{2}$ and ${ }^{5} \mathrm{D}_{0} \rightarrow{ }^{7} \mathrm{~F}_{4}$ transitions, with a concomitant decrease of the emission at $616 \mathrm{~nm}$ and $690 \mathrm{~nm}$, respectively, between 1.0 and 2.0 equivalent of added $\mathrm{Eu}^{3+}$ followed by a plateau for higher $\mathrm{Eu}^{3+}$ concentrations. Moreover, strong variations were also noticed on the ${ }^{5} \mathrm{D}_{0} \rightarrow{ }^{7} \mathrm{~F}_{4}$ transition at $700 \mathrm{~nm}$, for which the emission intensity kept increasing until the addition of 3 equivalents of $\mathrm{EuCl}_{3}$ (Figure 4). 
a)

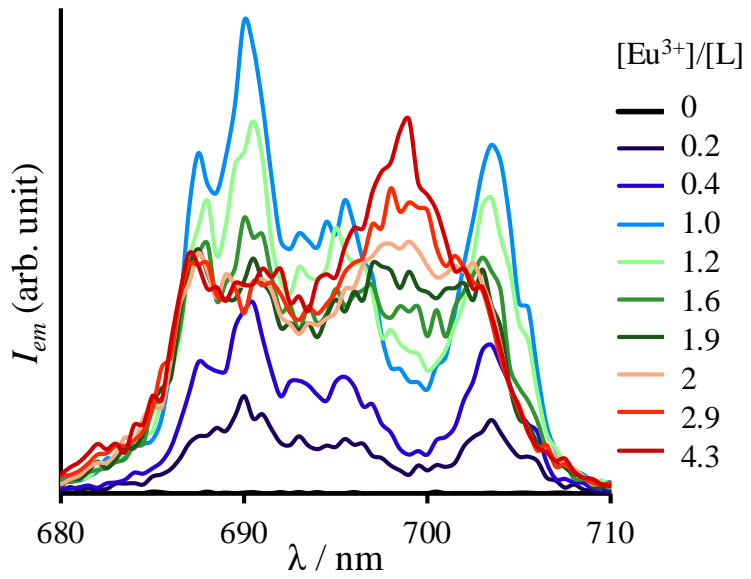

b)

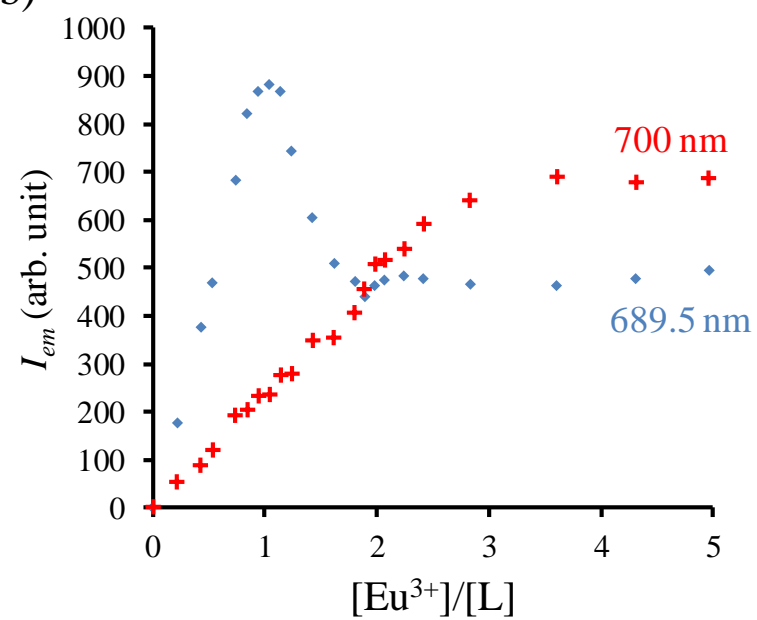

Figure 4. a) Enlargement of the variations on the ${ }^{5} \mathrm{D}_{0} \rightarrow{ }^{7} \mathrm{~F}_{4}$ transition of a solution of $\mathbf{L}$ upon titration by $\mathrm{EuCl}_{3}\left(0.01 \mathrm{M} \mathrm{TRIS} / \mathrm{HCl}, \mathrm{pH}=7.1, \lambda_{\text {exc }}=267 \mathrm{~nm}\right)$. b) Evolution of the emission intensity at $689.5 \mathrm{~nm}$ and $700 \mathrm{~nm}$ as a function of the $\left[\mathrm{Eu}^{3+}\right] /[\mathrm{L}]$ ratio.

The global analysis of the UV-Vis absorption and spectrofluorometric titration data with europium was performed by using the Specfit software. ${ }^{21}$ Data could be nicely reproduced by implementing a model including two coordination complexes of 1:1 and 2:1 Eu:L stoichiometric ratios, respectively, and a third species corresponding to the formation of larger supramolecular adducts, which was attributed to a 3:1 stoichiometry. Similar trends were also observed for the absorption and emission titrations with $\mathrm{TbCl}_{3}$ (Figure S1 and S2). The evolution of the luminescence intensities recorded for $\mathrm{Eu}^{3+}$ at $615 \mathrm{~nm}$ and $\mathrm{Tb}^{3+}$ at $545 \mathrm{~nm}$ as well as their corresponding fits are displayed in Figure S3 and Figure S4. Results were indicative of the formation of a highly stable 1:1 complex, which conditional stability constant is too high to be determined accurately by the given method. However, the conditional stepwise formation constants of the $\mathrm{Eu}_{2} \mathbf{L}$ and $\mathrm{Eu}_{3} \mathbf{L}$ species were estimated to $\log \beta\left(\mathrm{Eu}_{2} \mathbf{L}\right)=5.4(1)$ and $\log \beta\left(\mathrm{Eu}_{3} \mathbf{L}\right)=4.4(3)$, respectively $\left([\mathbf{L}]=5.0 \times 10^{-5} \mathrm{M}, \mathrm{TRIS} / \mathrm{HCl} 0.01 \mathrm{M}, \mathrm{pH}=7.1, \lambda_{\mathrm{exc}}=267\right.$ $\mathrm{nm})$. The corresponding species distribution diagram is depicted in Figure 5. The calculated emission $\left(\mathrm{Ln}=\mathrm{Eu}\right.$ and $\mathrm{Tb}$ ) and absorption spectra $(\mathrm{Ln}=\mathrm{Eu})$ of the $\operatorname{Ln} \mathbf{L}, \operatorname{Ln}_{2} \mathbf{L}$ and $\operatorname{Ln}_{3} \mathbf{L}$ species are displayed in Figure S5-S6. It is worth mentioning that at that $\mathrm{pH}$, the protonation states of the different species could not be determined accurately, and $\mathrm{pH}$ dependence of the emission spectra of a equimolar mixture of $\mathrm{Eu}$ and $\mathrm{L}$ clearly shows large variations in the $\mathrm{pH}$ range from 4.52 to 10.95 (Figure S7). 


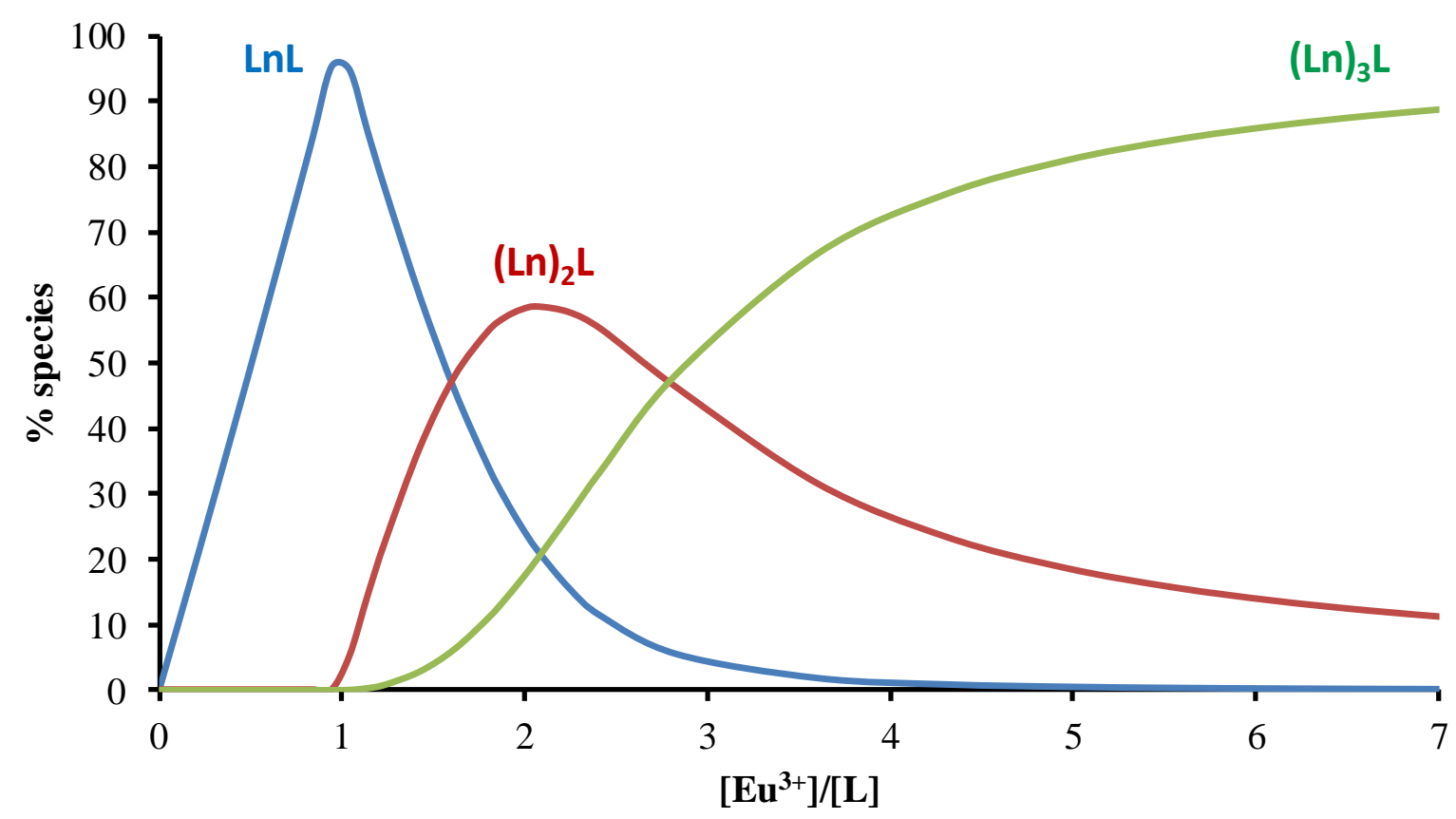

Figure 5. Theoretical representation of the species formed upon addition of $\mathrm{LnCl}_{3}(\mathrm{Ln}=\mathrm{Eu}$, $\mathrm{Tb})$ in an aqueous solution of ligand $\mathbf{L}\left([\mathbf{L}]=5.00 \times 10^{-5} \mathrm{M}, \mathrm{TRIS} / \mathrm{HCl} 0.01 \mathrm{M}, \mathrm{pH}=7.1\right.$, calculated with $\log \beta_{\mathrm{LnL}}=15.7, \log \beta_{(\operatorname{Ln}) 2 \mathrm{~L}}=21.1$ and $\left.\log \beta_{(\operatorname{Ln}) 3 \mathrm{~L}}=25.5\right)$.

\section{Isolation of the [LnL] complexes and X-ray crystal structure of the Eu complex}

The $[\mathrm{LnL}]$ complexes $(\mathrm{Ln}=\mathrm{Eu}, \mathrm{Tb}$ and $\mathrm{Yb})$ could be isolated from equimolar mixtures of the ligand and $\mathrm{LnCl}_{3}$ salts in water after basicification with $\mathrm{NaOH}$. The complexes were isolated by precipitation and the elemental analysis confirmed the presence of salts. However, the isolated compounds could be characterized by mass spectrometry, evidencing the presence of the peaks for a [ $\mathbf{L n L}]$ composition with the expected isotopic distributions (Figure S7-12). In the case of europium, slow crystallization of a solution of the complex in water afforded microcrystals suitable for analysis by X-ray diffraction. Crystal data and structure refinement are summarized in Table S1. 

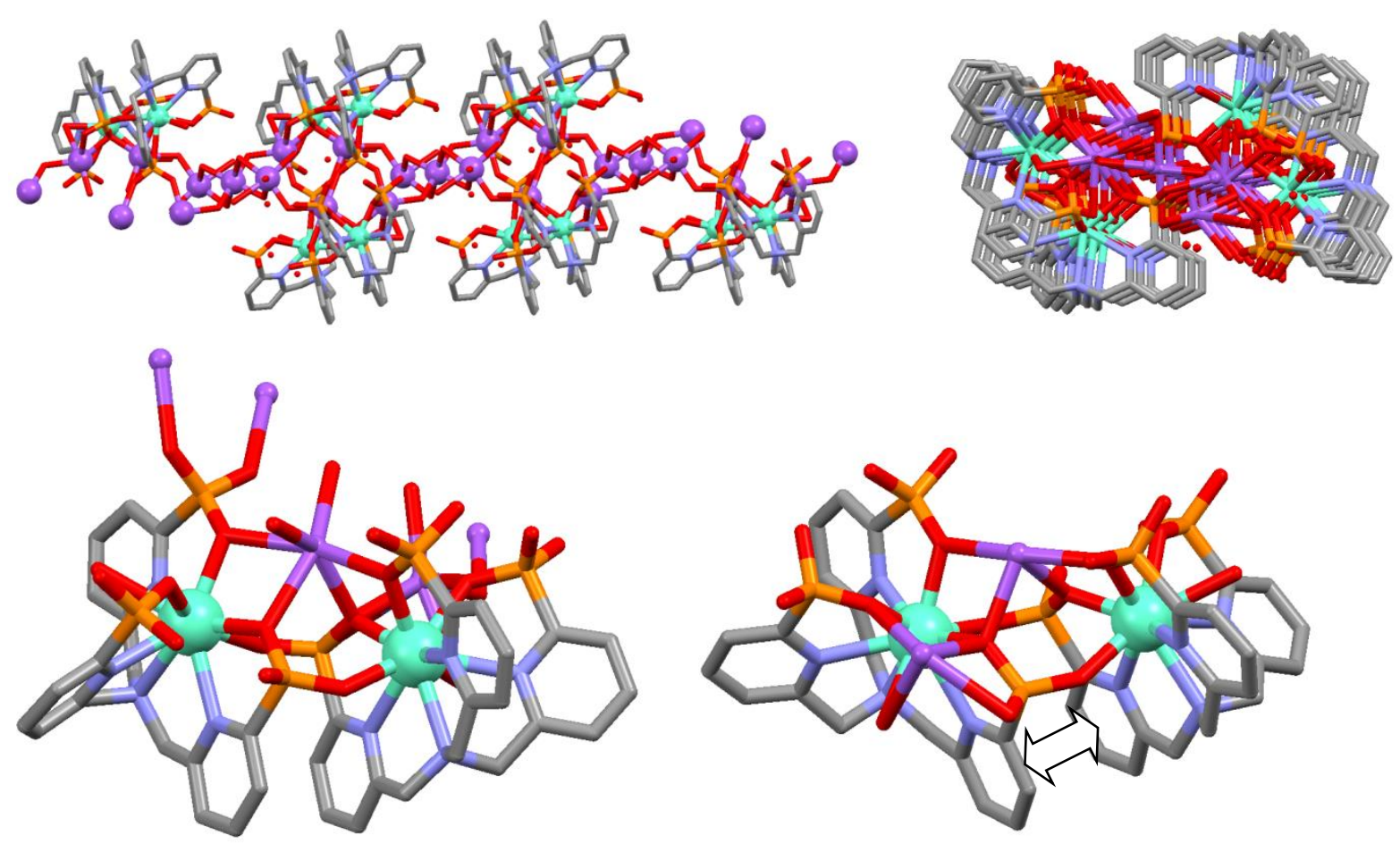

Figure 6. X-ray crystal structure of the $[\mathrm{EuL}]$ complex showing the assembly of dimers, interconnected through the network of $\mathrm{Na}^{+}$cations, along the $\mathrm{b}$ axis (top left) or perpendicular to the $\mathrm{b}$ axis (top right), the different coordination modes of the phosphonate functions (bottom left) and the numerous interactions resulting in the stabilisation of the dimeric units (bottom right, the double arrow highlights the $\pi \pi$ stacking interaction). $\mathrm{Eu}=$ green, $\mathrm{C}=$ grey, $\mathrm{N}=$ blue, $\mathrm{P}=$ orange, $\mathrm{O}=$ red, $\mathrm{Na}=$ violet.

The unit cell is composed of two dimeric units, comprising two [EuL] complexes, linked along the $b$ axis through an intricate network of bonds with seven sodium cations (Figure 4, top). Dimers are interconnected by the $\mathrm{Na}^{+}$cations, forming columns along the $b$ axis. Within the columns, the $\mathrm{Na}$ atoms are localized in the centre of the columns, while the aromatic parts of the ligands are found at the periphery. Looking in details at the dimeric units, the phosphonate functions of the ligands present a very large variety of coordinating mode. One is coordinated to the Eu cation with a single bond of one $\mathrm{O}$ atom. In a second one, one oxygen atom is coordinated to the $\mathrm{Eu}$ atom and the two remaining $\mathrm{O}$ atom are linked to $\mathrm{Na}^{+}$cation with distances of 2.272 and $2.504 \AA$, the longest one probably corresponding to the $\mathrm{P}=\mathrm{O}$ double bond. Finally, for one of the phosphonate function, one $\mathrm{O}$ atom is linked to the Eu atom and is bridging a central $\mathrm{Na}$ cation, and a second oxygen atom of this function is coordinated to the $\mathrm{Eu}$ atom of the second complex. For these phosphonate functions, a height membered 
$\mathrm{Eu}(\mathrm{OPO})_{2} \mathrm{Eu}$ metallacycle is formed, as often observed in dimeric Ln phosphonate complexes. ${ }^{22,23}$

The Eu cations are nine coodinated by the central $\mathrm{N}$ atom, the three $\mathrm{N}$ atoms of the pyridyl rings, three $\mathrm{O}$ atoms of the three phosphonate functions, an $\mathrm{O}$ atom of a phosphonate function from the neighbouring EuL complex, and a water molecule. It is worth noting that the analogue ligand bearing three carboxylic acid functions in place of the phosphonic ones in our ligand has been extensively studied, ${ }^{24}$ and the X-ray crystal structure of the Eu complex also displayed a coordination number of nine. Interestingly, both complexes crystallize as dimers, in which the two monomeric [EuL] units are linked together by the bridging of carboxylate or phosphonate functions. However, the supplementary stacking interaction is not observed in the case of carboxylate functions, as was observed for the free ligands (vide supra).

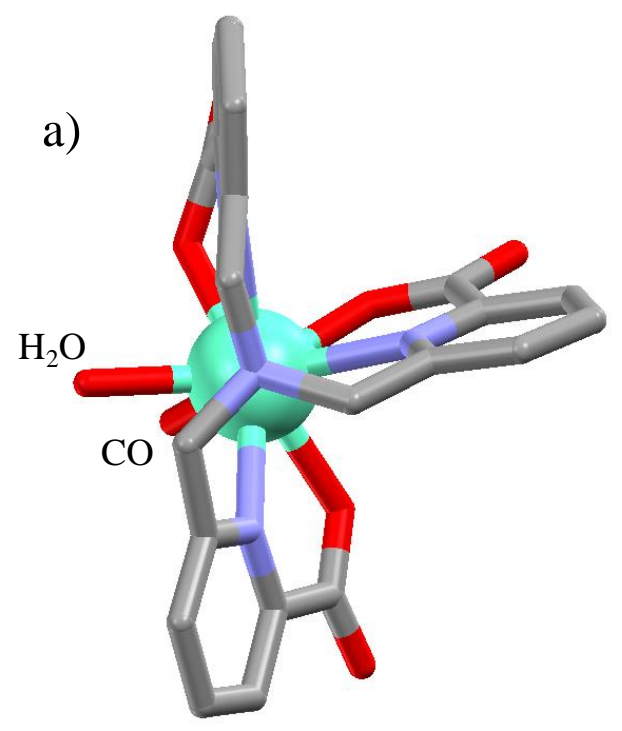

b)

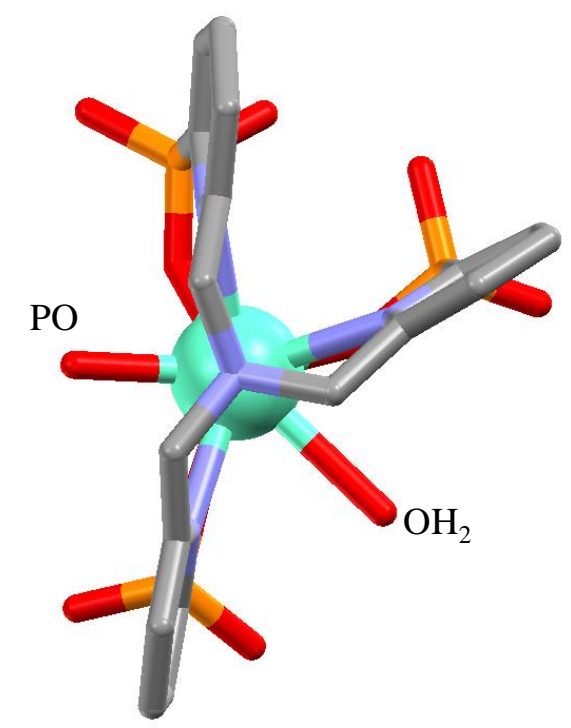

Figure 7. Views along the $\mathrm{N}_{\text {tert }}$-Eu bonds of the coordination spheres of Eu for the carboxylated analogue (left) ${ }^{24}$ and the phosphonated one (right, $\mathrm{CO}$ and PO respectively refer to the oxygen atoms of the bridging carboxylate and phosphonate functions (see text) and $\mathrm{H}_{2} \mathrm{O}$ to the coordinated water molecule).

Looking at the coordination sphere around the Eu atoms (Figure 7), two pyridyl rings are placed at opposite positions, while the third one forms an angle of $c a 60^{\circ}$ with the average plane formed by the two first ones. The net result of the stacking interaction and of the bulkiness of the phosphonate functions is a displacement of the water molecule from a position adjacent to the bridging carboxylate function to the opposite in the phosphonated complex. It also 
resulted in a flattening of the angles formed by the two opposite pyridyl strands. Considering the three atoms composing a tridentate unit (the tertiary $\mathrm{N}$ atom, the $\mathrm{N}$ atom of the pyridyl and the $\mathrm{O}$ atom of the carboxylate or phosphonate units), the average angles between the planes of the coordinating arms in opposite directions are $21.4^{\circ}$ for the phosphonated complex $\left(44.1^{\circ}\right.$ for the carboxylated one), with an almost planar pentadentate unit formed by these opposite strands as observed in disubstituted 6,6"-terpyridyl pentadentate ligands. ${ }^{25}$

\section{Spectroscopic properties of the ligand and of the $[\mathrm{LnL}]$ complexes $(\mathrm{Ln}=\mathrm{Eu}, \mathrm{Tb}$ and $\mathrm{Gd})$}

Table 2 summarizes the main spectroscopic properties of the ligand and complexes in water (TRIS buffer, pH 7.0 or pD 7.4). As can be seen in Figure 8 and Table 2, the UV-Vis absorption spectrum of the ligand and complexes are very similar, with a maximum around 267-270 nm, corresponding to $\pi \rightarrow \pi^{*}$ transitions centred on the ligand.

Table 2. Main spectroscopic properties of the [LnL] complexes in aqueous solutions (TRIS/H(D)Cl, $\mathrm{pH}=7.0$ or $\mathrm{pD}=7.4$ ).

\begin{tabular}{|l|c|c|c|c|}
\hline & Absorption & \multicolumn{3}{|c|}{ Luminescence } \\
\hline & $\begin{array}{c}\lambda_{\max } / \mathrm{nm} \\
\left(\varepsilon / \mathrm{M}^{-1} . \mathrm{cm}^{-1}\right)\end{array}$ & $\begin{array}{c}\tau_{H 2 O} / \mu \mathrm{s} \\
\left(\tau_{D 2 O} / \mu \mathrm{s}\right)\end{array}$ & $q^{\mathrm{a}}$ & $\begin{array}{c}\Phi_{H 2 O} / \% \\
\left(\Phi_{D 2 O} / \%\right)\end{array}$ \\
\hline $\mathbf{L}$ & $268(14500)$ & & - & - \\
\hline $\mathrm{EuL}$ & $267(12300)$ & $580(1910)$ & 1.1 & $4.4(19)$ \\
\hline $\mathrm{TbL}$ & $267(12300)$ & $1570(2490)$ & 0.9 & $11(18)$ \\
\hline $\mathrm{YbL}$ & $270(14200)$ & $-^{\mathrm{b}}(17.0)$ & - & $0.1(1.2)$ \\
\hline
\end{tabular}

${ }^{\text {a }}$ calculated according to reference 26 . estimated errors are $\pm 1 \mathrm{~nm}$ for $\lambda, 5 \%$ on $\varepsilon, 10 \%$ on $\tau$ and $15 \%$ on $\Phi \cdot{ }^{\mathrm{b}}$ too short to be determined. 


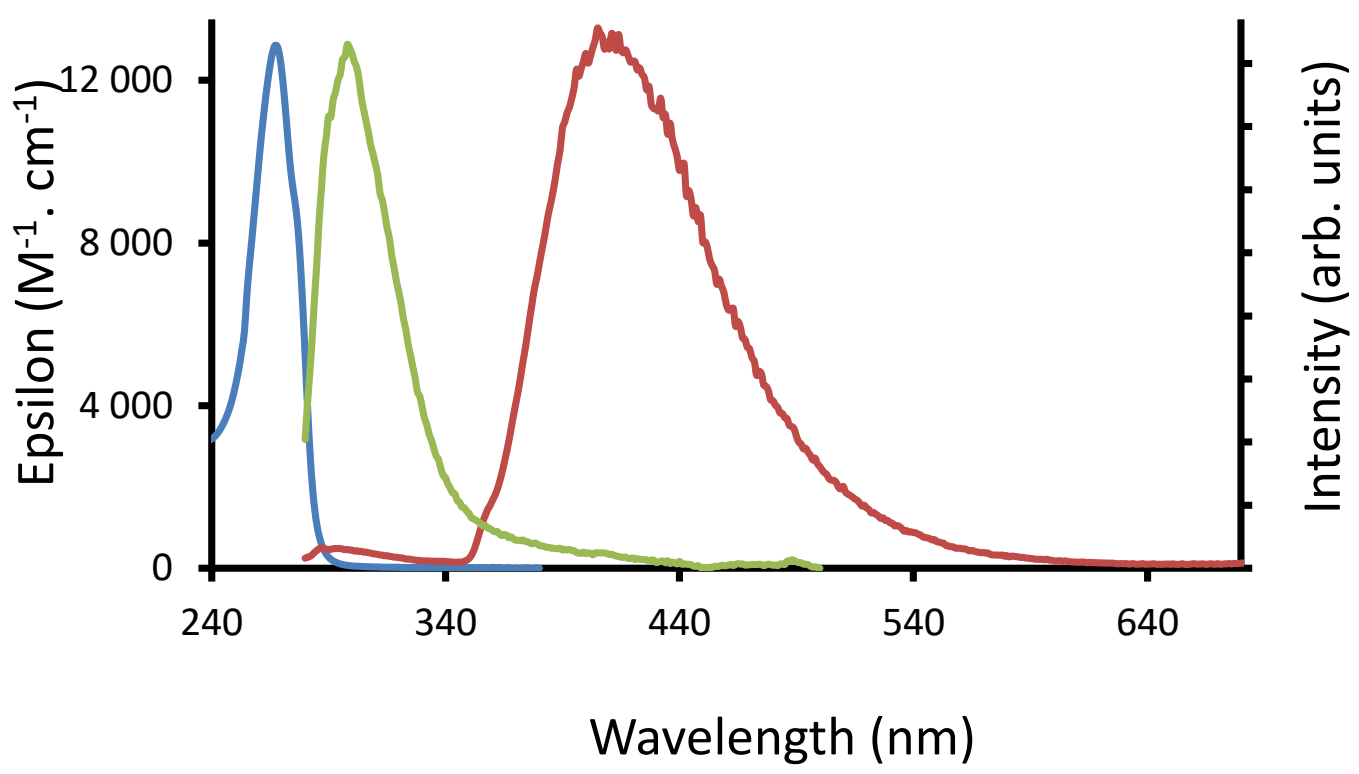

Figure 8. UV-Vis absorption spectra of $[\mathrm{Tb} \mathbf{L}]\left(\mathrm{H}_{2} \mathrm{O}\right.$, blue), and fluorescence (green, r.t.) and phosphorescence (red, $77 \mathrm{~K}$, TRIS-HCl, pH 7.0/Glycerol 9/1 mixture) spectra of the [GdL] complex.

To get insights into the ligand centred energy levels in the complexes, the spectroscopically silent Gd complex was prepared by mixing stoichiometric amounts of the ligand and Gd in water. The fluorescence spectrum was recorded at room temperature, while the phosphorescence spectrum was recorded in the time-resolved mode (time delay $=5 \mathrm{~ms}$ ) at $77 \mathrm{~K}$ in the presence of glycerol (Figure 8). The ${ }^{1} \pi \pi^{*}$ and ${ }^{3} \pi \pi^{*}$ level were determined to be respectively at 33600 and $24600 \mathrm{~cm}^{-1}$ and the phosphorescence lifetime was determined to be $73 \mathrm{~ms}$ at $77 \mathrm{~K}$. A comparison of the energy levels of the singlet absorption band and of the ${ }^{3} \pi \pi^{*}$ state for the Gd complex of $\mathbf{L}$ with that of the $\mathrm{La}, \mathrm{Lu}$ or $\mathrm{Gd}$ complexes of some pyridyl carboxylated analogues ${ }^{27}$ reveals that the carboxylate function systematically displaces the energy levels towards lower energy. This shift corresponds to $c a 800 \mathrm{~cm}^{-1}$ for the singlet absorption band (from 267-270 $\mathrm{nm}$ for $\mathbf{L}$ and its $\mathbf{L n}$ complexes to $274 \mathrm{~nm}$ for pyridyl carboxylate ligands) and $c a 600 \mathrm{~cm}^{-1}$ for the ${ }^{3} \pi \pi^{*}$ (at $24600 \mathrm{~cm}^{-1}$ for $\mathrm{GdL}$ and ca $24000 \mathrm{~cm}^{-1}$ for the carboxylated ligands ${ }^{27}$ ). This energy lowering is to be associated to the higher electronic delocalization in the carboxylated version as a result of the $\mathrm{sp}^{2}$ character of the carbon atom, in contrast to the $\mathrm{sp}^{3}$ character of the phosphorous atom. 


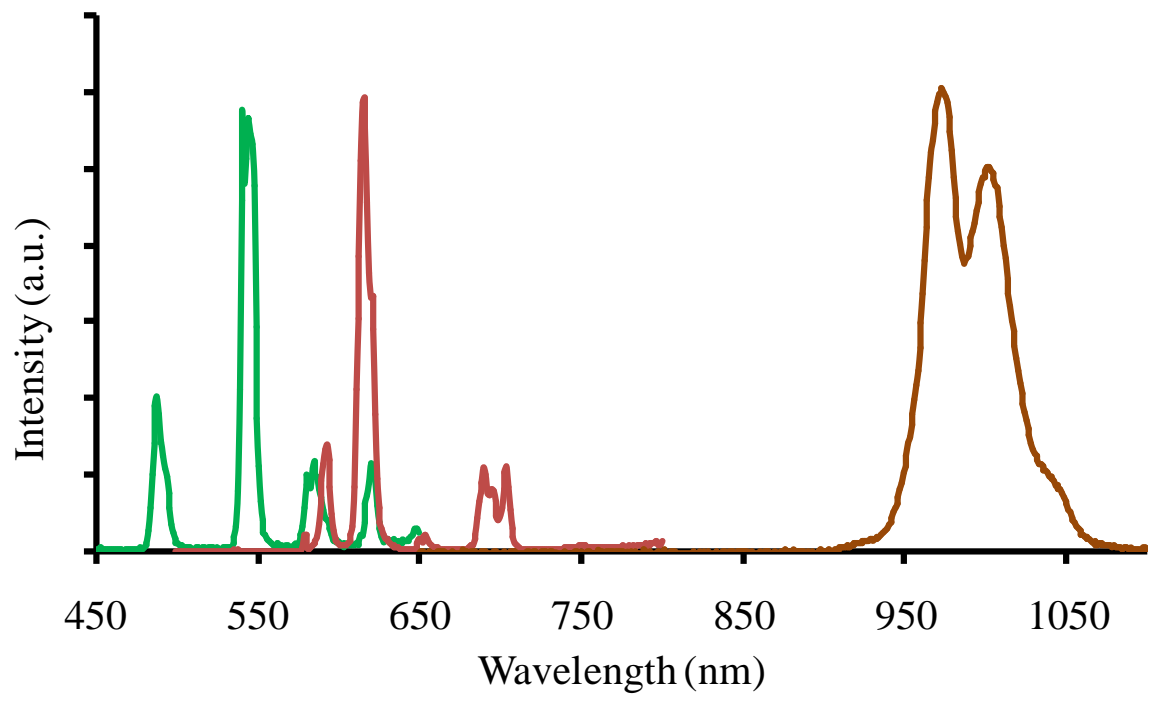

Figure 9. Luminescence spectra of $[\mathrm{Tb} \mathbf{L}],[\mathrm{EuL}]$ and $[\mathrm{YbL}]$ in water upon ligand excitation (normalized to their maximum of emission, $\lambda_{\mathrm{exc}}=269 \mathrm{~nm}, \mathrm{H}_{2} \mathrm{O}$, TRIS/HCl $0.01 \mathrm{M}, \mathrm{pH} 7.0$ ).

Upon excitation into the ligand absorption bands, all complexes ( $\mathrm{Ln}=\mathrm{Eu}, \mathrm{Tb}$ and $\mathrm{Yb})$ display the characteristic emission pattern of the $f-f$ Ln emission bands in the green $\left({ }^{5} \mathrm{D}_{4} \rightarrow{ }^{7} \mathrm{~F}_{\mathrm{J}}\right.$, transitions of Tb with $J=6$ to 3), red $\left({ }^{5} \mathrm{D}_{0} \rightarrow{ }^{7} \mathrm{~F}_{\mathrm{J}}\right.$, transitions of Eu with $J=0$ to 4$)$ and NIR $\left({ }^{2} \mathrm{~F}_{5 / 2} \rightarrow{ }^{2} \mathrm{~F}_{7 / 2}\right.$, transition of $\mathrm{Yb}$ ) regions (Figure 9$)$. The observed overall luminescence quantum yields are modest for all complexes and almost half of those generally observed for luminescent complexes based on carboxylated pyridine. ${ }^{26,28}$ All luminescence decay profile could be nicely fitted with mono-exponential components, pointing to single species in solutions or to different species being in rapid kinetic equilibrium. In the case of $\mathrm{Eu}$ and $\mathrm{Tb}$, the hydration numbers were determined to be one according to the methodology developed by Beeby and co-workers. ${ }^{26}$ The presence of a water molecule in the first coordination sphere is probably an important factor explaining the modest luminescence quantum yield. In addition, the energy gap between the ${ }^{5} \mathrm{D}_{4}$ or ${ }^{5} \mathrm{D}_{0}$ excited states of $\mathrm{Tb}$ or Eu, and the triplet state of the ligand amount to 4400 and 7200 $\mathrm{cm}^{-1}$, respectively. These gaps are quite important and are not favourable to good ${ }^{3} \pi \pi^{*} \rightarrow \mathrm{Ln}^{*}$ energy transfer according to the criteria proposed by Latva and co-workers. ${ }^{29}$

Unfortunately, the excited state lifetime of the $\mathrm{Yb}$ complex was too short to be accurately determined in water probably because of the presence of a water molecule in the first coordination sphere. Unless they are perfectly shielded from first sphere water molecules, ${ }^{28} \mathrm{Yb}$ 
complex rarely reach the $\mu$ s timescale. However, in deuterated water the complex displays very decent quantum yield $(1.2 \%)$ and lifetime $(15 \mu \mathrm{s})$.

When comparing the solid state structure and the data in solution, a puzzling question arises. If the dimer is disrupted in solution, the bridging phosphonate functions should live the place to an additional water molecule, resulting in a hydration number of two, while one is obtained for Eu and $\mathrm{Tb}$. When considering mass spectrometric data (Figure S7-S12), molecular peaks corresponding to the monomers are clearly observed. However, one can notice the presence of small additional peaks in the spectrum of Eu corresponding to dimers, such as the $\left[\left(\mathrm{EuLH}_{2}\right)_{2} \mathrm{Na}\right]^{-}$observed at $1378.87 \mathrm{~m} / \mathrm{z}$ units (calculated for $\mathrm{C}_{36} \mathrm{H}_{34} \mathrm{~N}_{8} \mathrm{P}_{6} \mathrm{O}_{18} \mathrm{Eu}_{2} \mathrm{H}_{4} \mathrm{Na} ; 1378.87$, Figure S7). The corresponding $\left[\left(\mathrm{YbLH}_{2}\right)_{2} \mathrm{H}\right]^{-}$dimer displays a broad peak around $1400 \mathrm{~m} / \mathrm{z}$ unit (Figure S11) and small peaks corresponding to the doubly charged dimer $\left[(\mathrm{TbLHNa})_{2}\right]^{2-}$ (at $707.44 \mathrm{~m} / \mathrm{z}$ for example) appear between the peaks of the singly charged monomer (Figure S10). However, it is very difficult to interpret such mass spectrometry data as the main peak of the monomer observed may result from the dissociation of the dimers in the electrospray process, while the appearance of peaks for the dimer may also result from association of monomers during the evaporation of the solvent from the micro droplets. Finally, NMR spectra of the $\mathrm{Eu}$ and $\mathrm{Yb}$ complexes point to a clear $C_{3}$ symmetry in $\mathrm{D}_{2} \mathrm{O}$ solutions at room temperature (Supp. Inf. Figure S13 and S14). When coordinated by bridging phosphonate functions as observed in the solid state structure of $\mathrm{Eu}$, the dimer would be expected to have a $C_{2}$ symmetry at best, with three sets of non-equivalent pyridyl arms. Observation of a single set thus points to the presence of a monomer in solution, or to a very rapid exchange between the isomers of a dimer, with a dissociative mechanism.

\section{Conclusion}

Ligand $\mathbf{L H}_{6}$ could readily be synthesized at the gram scale using a four step protocol. The $C_{3}$ symmetrical ligand appeared to be well suited for the coordination with lanthanide cations and the various spectroscopic titrations revealed the formation of species having 1:1; $1: 2$ and 1:3 stoichiometric ratii, the thermodynamic stability of the species with the $1: 1$ ratio appearing very large at neutral $\mathrm{pH}$. At equimolar concentrations of ligand and lanthanide cations, the 1:1 species could be isolated and characterized, as evidenced by the X-ray crystal structure of the Eu complex. The structure showed the cation to be embedded into the cavity 
formed by the three pyridyl arms of the ligand with the phosphonate functions being implicated in a large network of $\mathrm{H}^{+}, \mathrm{Na}^{+}$or $\mathrm{Eu}^{3+}$ bonding interactions. The structure also revealed the tendency of two complexes to associate in the solid state thanks to the concomitant action of $\pi$ $\pi$ stacking interactions, intercomplex phosphonate bridges and intermediate $\mathrm{Na}^{+}$bridging. In solution, the spectroscopic properties of the $\mathrm{Eu}$ and $\mathrm{Tb}$ complexes are in agreement with the presence of a water molecule in the first coordination sphere of the complexes, in agreement with the solid state structure, but electrospray mass spectrometry and NMR data both point to a monomeric structure in solution. Whether these results can be interpreted by rapid exchange within the monomeric units in a dimeric species or by a dissociation with a decrease of the coordination number is unfortunately not fully elucidated.

\section{Experimental section}

General Methods. Solvents and starting materials were purchased from Aldrich, Acros and Alfa Aesar and used without further purification. IR spectra were recorded on a Perkin Elmer Spectrum One Spectrophotometer as solid samples and only the most significant absorption bands are given in $\mathrm{cm}^{-1}$. Elemental analysis and mass spectrometry analysis were carried out by the Service Commun d'Analyses of the University of Strasbourg. Electrospray ionization mass measurements were performed on a microTOF II spectrometer in the negative mode using water as solvent. ${ }^{1} \mathrm{H},{ }^{31} \mathrm{P}$ and ${ }^{13} \mathrm{C}$ NMR spectra and $2 \mathrm{D}$ experiments were recorded on Avance 300 and Avance 400 spectrometers operating at 300 and $400 \mathrm{MHz}$ for ${ }^{1} \mathrm{H}$, respectively. Chemical shifts are reported in ppm, with residual protonated solvent as internal reference. ${ }^{31}$ When unspecified, coupling constants refer to $\mathrm{H}-\mathrm{H}$ coupling. The given $\mathrm{pH}$ values are corrected for the deuterium isotopic effects $(\mathrm{pD}=$ apparent $\mathrm{pH}+0.4) .{ }^{32}$ Compound 2 was obtained according to literature procedures. $^{13}$

Synthesis of compound 3. A mixture of compound 2 (2.0 g, $7.6 \mathrm{mmol}, 4.5$ eq.), acetaldehyde ammonia trimer trihydrate $(310 \mathrm{mg}, 1.7 \mathrm{mmol}, 1.0 \mathrm{eq}$.), potassium carbonate $(1.05 \mathrm{~g}, 7.6 \mathrm{mmol}$, 4.5 eq.), and potassium iodine ( $1.27 \mathrm{~g}, 7.6 \mathrm{mmol}, 4.5$ eq.) in acetonitrile ( $30 \mathrm{~mL})$ was refluxed for 2 hours. The reaction mixture was cooled to r.t and the solvent was evaporated. The residue was extracted with $\mathrm{CH}_{2} \mathrm{Cl}_{2}$ /water, dried over $\mathrm{Na}_{2} \mathrm{SO}_{4}$, filtered and evaporated under vacuum. The crude product was purified by alumina gel column chromatography (eluent: $\mathrm{CH}_{2} \mathrm{Cl}_{2} / \mathrm{MeOH}$ 
from 100:00 to 95:5 in 40 minutes) to give the desired product as a yellow oil (836 $\mathrm{mg}, 1.2$ mmol, 70\%). ${ }^{1} \mathrm{H}-\mathrm{NMR}\left(400 \mathrm{MHz}, \mathrm{CDCl}_{3}\right): \delta$ 7.86-7.69 (m, 9H), 4.35-4.10 (m, 12H), 3.95 (s, $6 \mathrm{H}), 1.33(\mathrm{t}, J=7.1 \mathrm{~Hz}, 18 \mathrm{H}) .{ }^{13} \mathrm{C}-\mathrm{NMR}\left(126 \mathrm{MHz}, \mathrm{CDCl}_{3}\right): \delta 160.32(\mathrm{~d}, J=22.3 \mathrm{~Hz}), 151.44$ $(\mathrm{d}, J=227 \mathrm{~Hz}), 136.42(\mathrm{~d}, J=12.5 \mathrm{~Hz}), 126.50(\mathrm{~d}, J=25.1 \mathrm{~Hz}), 125.27(\mathrm{~d}, J=3.8 \mathrm{~Hz}), 62.96$ $(\mathrm{d}, J=6.0 \mathrm{~Hz}), 59.90,16.40(\mathrm{~d}, J=6.1 \mathrm{~Hz}) .{ }^{31} \mathrm{P}-\mathrm{NMR}\left(162 \mathrm{MHz}, \mathrm{CDCl}_{3}\right): \delta 10.77 . \mathrm{ESI} / \mathrm{MS}$ : Calcd. for $\mathrm{C}_{30} \mathrm{H}_{45} \mathrm{~N}_{4} \mathrm{O}_{9} \mathrm{P}_{3}+\mathrm{H}^{+}$: 699.24; found: 699.24.

Synthesis of LH6. Compound 3 (160 mg, $0.23 \mathrm{mmol}$ ) was dissolved in $5 \mathrm{~mL} 6 \mathrm{M}$ aqueous $\mathrm{HCl}$ and refluxed for $48 \mathrm{~h}$. The solution was evaporated to dryness and $\mathbf{L H}_{6}$ was isolated as a hydrated di-hydrochloride salt (128 mg, $0.21 \mathrm{mmol}, 91 \%)$. ${ }^{1} \mathrm{H}-\mathrm{NMR}\left(400 \mathrm{MHz}, \mathrm{D}_{2} \mathrm{O}\right): \delta 8.31$ $(\mathrm{td}, J=7.8 ; 3.9 \mathrm{~Hz}, 3 \mathrm{H}), 7.96-7.89(\mathrm{~m}, 6 \mathrm{H}), 4.44$ (s, 6H). ${ }^{13} \mathrm{C}-\mathrm{NMR}\left(126 \mathrm{MHz}, \mathrm{D}_{2} \mathrm{O}\right): \delta 152.77$ $(\mathrm{d}, J=7.9 \mathrm{~Hz}), 151.93(\mathrm{~d}, J=176 \mathrm{~Hz}), 146.73$ (d, $J=8.9 \mathrm{~Hz}), 128.67$ (d, $J=11.1 \mathrm{~Hz}), 128.2$, 56.64. ${ }^{31} \mathrm{P}-\mathrm{NMR}$ (162 MHz, $\mathrm{D}_{2} \mathrm{O}$ ): $\delta$-3.04. ESI/MS: Calcd. for $\mathrm{C}_{18} \mathrm{H}_{21} \mathrm{~N}_{4} \mathrm{O}_{9} \mathrm{P}_{3}+\mathrm{H}^{+}: 531.05$; found: 531.06. Anal. Calcd for $\mathrm{C}_{18} \mathrm{H}_{21} \mathrm{~N}_{4} \mathrm{O}_{9} \mathrm{P}_{3} .2 \mathrm{HCl} . \mathrm{H}_{2} \mathrm{O}$ : C, 34.80; H, 4.06; N, 9.02. Found: C, $35.11 ; \mathrm{H}, 4.34 ; \mathrm{N}, 8.80$.

Synthesis of the complexes, general procedure. Ligand $\mathbf{L H}_{6} .2 \mathrm{H}_{2} \mathrm{O}$ ( $c$ a $50 \mathrm{mg}, 1.0$ eq.) was dissolved in water. The $\mathrm{pH}$ of the solution was raised to 7.0 by addition of diluted $\mathrm{NaOH}$ and $\mathrm{LnCl}_{3} \cdot \mathrm{xH}_{2} \mathrm{O}$ salts ( $\mathrm{Ln}=\mathrm{Eu}, \mathrm{Tb}$ and $\mathrm{Yb}, 1$ eq.) was added. The $\mathrm{pH}$ of the solution was raised to 7.0 by addition of diluted $\mathrm{NaOH}$ and the solution was stirred for one hour. The complex was purified by reverse phase column chromatography (eluent: $\mathrm{H}_{2} \mathrm{O} / \mathrm{MeOH} 95: 5$ ) to give the desired product as white powders.

[TbL]. yield: $60 \%$. ESI/MS: Calcd. for $\left[\mathrm{C}_{18} \mathrm{H}_{17} \mathrm{~N}_{4} \mathrm{O}_{9} \mathrm{P}_{3} \mathrm{TbNaH}\right]^{+}: m / z=706.93$; found: 706.94 (35\%); Calcd. for $\left[\mathrm{C}_{18} \mathrm{H}_{20} \mathrm{~N}_{4} \mathrm{O}_{9} \mathrm{P}_{3} \mathrm{~Tb}\right]^{2+}: 341.97$; found: 341.98 (100\%). IR (cm ${ }^{-1}$, ATR): $v$ $3336,1651,1593,1446,1111,1074,987$.

[EuL]. yield: 58\%. ${ }^{1} \mathrm{H}-\mathrm{NMR}\left(400 \mathrm{MHz}, \mathrm{D}_{2} \mathrm{O}\right): \delta 6.62$ (s, br, 3H), 6.21 (s, br, 3H), 5.04 (s, br, 3H), -0.16 (s, br, 6H). ${ }^{31} \mathrm{P}-\mathrm{NMR}\left(162 \mathrm{MHz}, \mathrm{D}_{2} \mathrm{O}\right): \delta$ 29.12. ESI/MS: Calcd. for $\left[\mathrm{C}_{18} \mathrm{H}_{19} \mathrm{~N}_{4} \mathrm{O}_{9} \mathrm{P}_{3} \mathrm{Eu}\right]^{+}$: 678.94; found: 678.94 (98 \%); Calcd. for $\left[\mathrm{C}_{18} \mathrm{H}_{20} \mathrm{~N}_{4} \mathrm{O}_{9} \mathrm{P}_{3} \mathrm{Eu}\right]^{2+}$ : 338.97; found: 338.97 (100\%). Anal. Calcd for $\mathrm{C}_{18} \mathrm{H}_{18} \mathrm{~N}_{4} \mathrm{O}_{9} \mathrm{P}_{3} \mathrm{Eu} \cdot 6.5 \mathrm{NaCl} \cdot 4 \mathrm{H}_{2} \mathrm{O}: \mathrm{C}, 19.11 ; \mathrm{H}, 2.32 ; \mathrm{N}$, 4.95. Found: C, 19.11; H, 2.30; N, 4.61. IR (cm ${ }^{-1}$, ATR): v 3325, 2108, 1590, 1560, 1443, 1130 , 1067, 975.

[YbL]. Yield: 50\%. ${ }^{1} \mathrm{H}-\mathrm{NMR}\left(400 \mathrm{MHz}, \mathrm{D}_{2} \mathrm{O}\right.$ ): $\delta 16.39$ (s, br, 3H), 10.53 (s, br, 3H), 2.65 (s, br, 3H), -26.46 (s, br, 6H). ${ }^{31} \mathrm{P}-\mathrm{NMR}\left(162 \mathrm{MHz}, \mathrm{D}_{2} \mathrm{O}\right): \delta$ 43.9. ESI/MS: Calcd. for 
$\left[\mathrm{C}_{18} \mathrm{H}_{19} \mathrm{~N}_{4} \mathrm{O}_{9} \mathrm{P}_{3} \mathrm{Yb}\right]^{+}$: 699.96; found: $699.96(100 \%)$. Anal. Calcd for $\mathrm{C}_{18} \mathrm{H}_{18} \mathrm{~N}_{4} \mathrm{O}_{9} \mathrm{P}_{3} \mathrm{Yb} \cdot 9 \mathrm{NaCl} \cdot$ $3 \mathrm{H}_{2} \mathrm{O}: \mathrm{C}, 16.89 ; \mathrm{H}, 1.89$; N, 4.38. Found: C, 17.24; H, 2.06; N, 4.37. IR ( $\left.\mathrm{cm}^{-1}, \mathrm{ATR}\right): v 3203$, $1653,1593,1558,1457,1129,1062,970$.

Spectroscopic measurements. UV/vis absorption spectra were recorded on a Perkin Elmer lambda 950 or on a Specord spectrometer from Jena Analytics. Steady state emission spectra were recorded on an Edinburgh Instrument FLP920 spectrometer working with a continuous 450W Xe Lamp and a red sensitive R928 photomultiplier from Hamamatsu in Pelletier housing for visible detection (230 to $900 \mathrm{~nm}$ ) or a Hamamatsu R5 509-72 photomultiplier for the VisNIR part. All spectra were corrected for the instrumental functions. For emission spectra upon UV excitation, a $399 \mathrm{~nm}$ cutoff filter was used to eliminate second order artifacts. Phosphorescence lifetimes were measured on the same instrument working in the MultiChannel Spectroscopy (MCS) mode, using a Xenon flash lamp as the excitation source. For short $\mu$ s lifetimes, the intensity decay was corrected for the lamp intensity decay profile using a scattering solution of Ludox in water. Luminescence quantum yields were measured according to conventional procedures, ${ }^{33}$ with optically diluted solutions (optical density $<0.05$ ), using $\left[\mathrm{Ru}(\text { bipy })_{3} \mathrm{Cl}_{3}\right]$ in water $(\Phi=0.04)^{34}$ as reference for Eu, a bipyridine $\mathrm{Tb}$ complex, $\left[\operatorname{TbL}\left(\mathrm{H}_{2} \mathrm{O}\right)\right]$ in water $(\Phi=0.31)^{35}$ as reference for Tb, and cardiogreen (IR125) in $\mathrm{MeOH}(\Phi=$ 0.078 ) for $\mathrm{Yb}^{36}$ The errors are estimated to $10 \%$ on the lifetimes and $15 \%$ on the luminescence quantum yields.

Crystallography. Data were collected on a APEX II Brucker AXS diffractometer with MoK $\alpha$ radiation $(\lambda=0.71073 \AA)$. Structures were solved by direct methods (SIR92) ${ }^{37}$ and refined $\left(\right.$ SHELXL-2014/7) ${ }^{38}$ by full-matrix least-squares methods as implemented in the WinGX software package. ${ }^{39}$ An empirical absorption (multi-scan) correction was applied. Hydrogen atoms were introduced at calculated positions (riding model) included in structure factor calculation but not refined except for $\mathrm{H}$ atoms of the two water molecules in the structure of the ligand which have been found in the Fourier difference map and refined with DFIX and DANG restraint. $\mathrm{H}$ atoms on water molecule in the structure of the Eu complex have been omitted in the refinement. Refinement parameters are summarized in Table 1. Crystallographic data have been deposited to the Cambridge Crystallographic Data Center (CCDC number 1876208 for the ligand and 1876207 for the Eu complex). 
Acknowledgements. The French National Research Agency (ANR) is gratefully acknowledge for financial support (Neutrinos project $\left.n^{\circ} 16-C E 09-0015-02\right)$.

\section{References}

1/ a) J. Morrow, E. Jakab-Toth, Inorg. Chem. 2017, 56, 6029-6034. b) E. Boros, E.M. Gale, P. Caravan, Dalton Trans. 2015, 44, 4804-4818.

2/ a) S.J. Butler, L. Lamarque, R. Pal, D. Parker, Chem. Sci. 2014, 5, 1750-1756. b) A.T. Bui, M. Beyler, A. Grichine, A. Duperray, J.-C. Mulatier, Y. Guyot, C. Andraud, R. Tripier, S. Brasselet, O. Maury, Chem. Commun. 2017, 53, 6005-6008.

3/ a) S.V. Eliseeva, J.-C. G. Bünzli, Chem. Soc. Rev. 2010, 39, 189-227. b) N. Hildebrandt, L.J. Charbonnière, H.-G. Löhmannsröben, J. Biomed. Biotech. 2007, 79169.

4/ see for examples a) S. Procházková, J. Hranícek, V. Kubícek, P. Hermann Polyhedron, 2016, 11, 143-149. b) T. Krchova, V. Herynek, A. Galisova, J. Blahut, P. Hermann, J. Kotek, Inorg. Chem. 2017, 56, 2078-2091.

5/ J.-G. Mao, Coord. Chem. Rev. 2007, 251, 1493.

6/ K.H. Zangana, Magnetochemistry 2018, 4, 29-40.

7/ Y. Xu, S.-S. Bao, X.-D. Huang, L.-M. Zheng, Cryst. Growth Des. 2018, 18, 4045-4053.

8/ a) I. Lukes, J. Kotek, P. Vojtisek, P. Hermann, Coord. Chem. Rev. 2001, 216-217, $287-$

312. b) S. Abada, A. Lecointre, M. Elhabiri, L.J. Charbonnière, Dalton Trans. 2010, 39 , 9055-9062.

9/ a) F. Avecilla, J.A. Peters, C.F.G.C. Geraldes Eur. J. Inorg. Chem. 2003, 4179-4186. b)

A.D. Sherry, J. Ren, J. Huskens, E. Brücher, E. Toth, C. F. C. G. Geraldes, M.M.C.A. Castro, W. P. Cacheris, Inorg. Chem. 1996, 35, 4604-4612. 
10/ a) E. Balogh, C. Mato-Iglesias, C. Platas-Iglesias, E. Toth, K. Djanashvili, J. A. Peters, A. de Blas, T. Rodriguez-Blas, Inorg. Chem. 2006, 45, 8719-8728. b) L. Tei, M. Botta, C. Lovazzano, A. Barge, L. Milone, S. Aime, Magn. Reson. Chem. 2008, 46, S86-93. c) M. Elhabiri, S. Abada, M. Sy, A. Nonat, P. Choquet, D. Esteban-Gumez, C. Cassino, C. PlatasIglesias, M. Botta, L.J. Charbonnière, Chem. Eur. J. 2015, 21, 6535-6546.

11/ R.C. Holz, G.E. Meister, W. Dew. Horrocks, Jr Inorg. Chem. 1990, 29, 5183-5189.

12/ S.T. Frey, W. Dew. Horrocks, Jr Inorg. Chem. 1991, 30, 1073-1079.

13/ N. Souri, P. Tian, A. Lecointre, Z. Lemaire, S. Chafaa, J.-M. Strub, S. Cianférani, M. Elhabiri, C. Platas-Iglesias, L.J. Charbonnière, Inorg. Chem. 2016, 55, 12962-12974.

14/ J. Salaam, L. Tabti, S. Bahamyirou, A. Lecointre, O. Hernandez Alba, O. Jeannin, F. Camerel, S. Cianférani, E. Bentouhami, A.M. Nonat, L.J. Charbonnière Inorg. Chem. 2018, 57, 6095-6106.

15/ N. Souri, P. Tian, C. Platas-Iglesias, K.-L. Wong, A. Nonat, L.J. Charbonnière J. Am. Chem. Soc. 2017, 139, 1456-1459.

16/ A. Nonat, S. Bahamyrou, A. Lecointre, F. Przybilla, Y. Mély, C. Platas-Iglesias, F. Camerel, O. Jeannin, L.J. Charbonnière, to be published in J. Am. Chem. Soc. 2019, doi: $10.1021 /$ jacs.8b10932.

17/ Y. Mikata, Y. Nodomi, R. Ohnishi, A. Kizu, H. Konno, Dalton Trans. 2015, 44, 80218030 .

18/ C.F.G.C. Geraldes, A.D. Sherry, W.P. Cacheris, Inorg. Chem. 1989, 28, 3336.

19/ L. Prodi, M. Montalti, N. Zaccheroni, G. Pickaert, L. Charbonnière, R. Ziessel New J. Chem. 2003, 27, 134-139.

20/ J.-C.G. Bünzli, Chem. Rev. 2010, 110, 2729-2755.

21/ H. Gampp, M. Maeder, C. Meyer, A. Zuberbuhler, Talanta 1985, 32, 95.

22/ J. Goura, V. Chandrasekhar, Chem. Rev. 2015, 115, 6854.

23/ V. Chandrasekhar, P. Sasikumar, Dalton Trans. 2008, 6475. 
24/ Y. Bretonnière, M. Mazzanti, J. Pécaud, F.A. Dunand, A.E. Merbach, Inorg. Chem. 2001, $40,6737$.

25/ L. Charbonnière, S. Mameri, P. Kadjane, C. Platas-Iglesias, R. Ziessel Inorg. Chem. 2008, 47,3748 .

26/ A. Beeby, I.M. Clarckson, R.S. Dickins, S. Faulkner, D. Parker, L. Royle, A.S. de Sousa, J.A.G. Williams, M. Woods, J. Chem. Soc., Perkin Trans. 2, 1999, 493.

27/ G. Nocton, A. Nonat, C. Gateau, M. Mazzanti, Helv. Chim. Acta, 2009, 92, 2257.

28/ a) C. Guanci, G. Giovenzana, L. Lattuada, C. Platas-Iglesias, L.J. Charbonnière Dalton Trans. 2015, 44, 7654. b) M. Regueiro-Figueroa, B. Bensenane, E. Ruscsak, D. EstebanGómez, L.J. Charbonnière, G. Tyrcso, I. Tóth, A. de Blas, T. Rodriguez-Blas, C. PlatasIglesias, Inorg. Chem. 2011, 50, 4125.

29/ M. Latva, H. Takalo, V.-M. Mukkala, C. Matachescu, J.C. Rodriguez-Ubis, J. Kankare, J. Lumin. 1997, 75, 149.

30/ a) A.-T. Buy, M. Beyler, A. Grichine, A. Duperray, J.-C. Mulatier, Y. Guyot, C. Andraud, R. Tripier, S. Brasselet, O. Maury Chem. Commun. 2017, 53, 6005. b) A. D’Aléo, A. Bourdolle, S. Brustlein, T. Fauquier, A. Grichine, A. Duperray, P.L. Baldeck, C. Andraud, S. Brasselet, O. Maury Angew. Chem. Int. Ed. 2012, 51, 6622.

31/ H.E. Gottlieb, V. Kotlyar, A. Nudelman J. Org. Chem. 1997, 62 (21), 7512.

32/ K. Mikkelsen, S. O. Nielsen J. Phys. Chem. 1960, 64 (5), 632.

33/ Molecular Fluorescence: Principles and Applications, 2nd Edition - Valeur, B. and Berberan-Santos, M. N. 2013, Weinheim: Wiley-VCH.

34/ H. Ishida, S. Tobita, Y. Hasegawa, R. Katoh, K. Nozaki Coord. Chem. Rev. 2010, 254 (21), 2449.

35/ N. Weibel, L.J. Charbonnière, M. Guardigli, A. Roda, R. Ziessel, J. Am. Chem. Soc. 2004, $126(15), 4888$.

36/ R.C. Benson, H.A. Kues Phys. Med. Biol. 1978, 23 (1), 159. 
37/ A. Altomare, G. Cascarano, C. Giacovazzo, A. Guagliardi, M.C. Burla, G. Polidori, M. Camalli, J. Appl. Cryst. 1994, 27, 435.

38/ G.M. Sheldrick Acta Cryst. 2015, C71, 3.

39/ L. J. Farrugia J. Appl. Cryst. 2012, 45, 849. 